\title{
Reprogramación de las células no-beta del islote
}

\author{
Prof. Pedro L. Herrera
}

Departamento de Medicina Genética y Desarrollo, Universidad de Ginebra, Suiza

Usando métodos genéticos en ratones adultos para marcar células, y así rastrear y delinear los diferentes linajes celulares corporales en combinación con la ablación selectiva de tipos celulares específicos, descubrimos que el páncreas tiene la capacidad de regenerar células productoras de insulina mediante cambios de identidad funcional en células insulares no- $\beta$. Todas las células no- $\beta$ de los islotes tienen el potencial de adaptación para hacerse productoras de insulina.

Del mismo modo, las células insulares humanas $\alpha, y$ las $\gamma$, poseen igualmente la plasticidad adaptativa para convertirse en células productoras de insulina y sensibles a la glucosa. Nuestros estudios enfatizan la importancia de la arquitectura tridimensional de los islotes para promover la adaptabilidad de sus células endocrinas.

Esta plasticidad natural podría en principio utilizarse para reprogramar las células no- $\beta$ en células similares a $\beta$ para tratar la diabetes (DM). ¿Es posible estimular terapéuticamente la conversión celular en los islotes? Una ventaja adicional de forzar la producción de insulina en células no- $\beta$ es que conllevaría una reducción en la producción de glucagón en el paciente diabético.

En mi laboratorio intentamos elucidar los mecanismos moleculares de este fenómeno de reprogramación celular para desarrollar una estrategia terapéutica completamente nueva contra la DM. Curiosamente, a pesar de mostrar una secreción de insulina estimulada por glucosa y conducir a una remisión de la enfermedad cuando se trasplantan en ratones diabéticos, las células a humanas convertidas mantienen una firma genética típica de células a y muestran un fenotipo mixto. Esta característica podría ser muy valiosa, porque gracias a su carácter híbrido, estas células podrían evadir el ataque autoinmune.

Los libros de texto de biología nos enseñan que las células adultas maduras y completamente diferenciadas permanecen fijadas en la identidad que han adquirido al madurar y diferenciarse. Al inducir una modificación funcional en las células pancreáticas humanas para producir y secretar insulina en respuesta a la glucosa, demostramos que la capacidad de adaptación de nuestras células es mucho mayor de lo que se creía hasta ahora. Naturalmente, esta plasticidad celular probablemente no sea exclusiva del páncreas.

La reprogramación celular dirigida se perfila, entonces, como una vía prometedora para tratar no solo la DM, sino también otras enfermedades degenerativas causadas por una muerte celular masiva y prematura.

Palabras clave: reprogramación celular; diabetes.

\section{Bibliografía}

PMID: 20364121, PMID: 25141178, PMID: 30361701, PMID: 30760930. 


\section{Reprogramming of non-beta islet cells}

Prof. Pedro L. Herrera

Dept. Genetic Medicine \& Development, University of Geneva, Switzerland

Using methods of genetic (i.e., irreversible) cell labeling in mice to trace and delineate lineages of cells in the body, in combination with the selective ablation of specific cell types in vivo, we found that the adult pancreas has the ability to regenerate new functional insulin-producing cells through spontaneous cell identity changes occurring in islet non- $\beta$ - cells. All islet non- $\beta$-cells have the potential to become insulin producers.

We have subsequently shown that human $\alpha$ - and $y$-cells can also become glucosesensitive insulin-producing cells. Our studies also stress the importance of the islet threedimensional architecture to harness islet cell plasticity.

This plasticity could be exploited to reprogram non- $\beta$-cells into $\beta$-like cells to treat diabetes. Would it be possible to therapeutically promote the islet cell conversion in patients? One additional advantage of promoting insulin production by non- $\beta$-cells is that it would encompass a decreased glucagon production in autoimmune diabetes.

In the lab we are seeking to determine how to exploit this phenomenon of cellular reprogramming to propose an entirely new therapeutic strategy for diabetes. Interestingly, despite showing glucose-stimulated insulin secretion and leading to diabetes remission when transplanted into diabetic mice, converted human $\alpha$-cells maintain an $\alpha$-cell genetic signature and display a hybrid phenotype. This feature might be most valuable, because such a hybrid character could help evading the immune system when autoimmunity has developed.

Biology textbooks teach us that mature and fully differentiated adult cell types remain fixed in the identity they have acquired upon maturation and differentiation. By inducing non- insulin-producing human pancreatic cells to modify their function to produce and secrete insulin in response to glucose, we show that the adaptive capacity of our cells is much greater than previously thought. Moreover, human cell plasticity would not be exclusive to the pancreas. Direct reprogramming appears to be a promising avenue to treat not only diabetes but also other degenerative diseases, namely, diseases resulting from massive and premature cell death.

Key words: direct reprogramming; diabetes.

\section{Bibliografía}

PMID: 20364121, PMID: 25141178, PMID: 30361701, PMID: 30760930 